\section{Decline of Oxamyl Residues in Tomatoes in Cool, Modified- atmosphere Storage}

\author{
Brian D. McGarvey, Andres A. Reyes, and Mikio Chiba \\ Agriculture Canada Research Station, Vineland Station, Ont. LOR 2EO, \\ Canada
}

Additional index words. insecticide, nematicide, Lycopersicon esculentum

\begin{abstract}
Residues of the insecticide-nematicide oxamyl in tomatoes (Lycopersicon esculentum Mill.) declined more quickly during storage at $15 \mathrm{C}$ in modified atmospheres consisting of $1.5 \% \mathrm{O}_{2}+98.5 \% \mathrm{~N}_{2}$ or $1.5 \% \mathrm{O}_{2}+4.0 \% \mathrm{CO}_{2}+94.5 \% \mathrm{~N}_{2}$ than in air. $(21.0 \%$ $\mathrm{O}_{2}+79.0 \% \mathrm{~N}_{2}$ ). Fruit ripened more quickly in air than in either modified atmosphere. Chemical name used: $S$ - methyl $N^{\prime}, N^{\prime}$-dimethyl $-N$ - (methylcarbamoyloxy)1-thio-oxamimidate (oxamyl).
\end{abstract}

In several countries, oxamyl is a registered insecticide-nematicide used to control a number of nematode and insect pests of tomato; applications are permitted up to 1 day before harvest (Du Pont, 1981). Oxamyl is not registered in Canada for use on tomatoes, but tomatoes are imported into Canada from countries where oxamyl is registered for this crop (Du Pont, 1981). The United States' tolerance for oxamyl in tomatoes is $2 \mathrm{ppm}$; whereas in Canada, the maximum allowable residue in imported tomatoes is $0.1 \mathrm{ppm}$. Oxamyl degrades hydrolytically to oxamyl oxime and enzymatically to $\mathrm{N}, \mathrm{N}$ - dimethyl-1-cyanoformamide (DMCF) (Harvey and Han, 1978). DMCF, but not oxamyl oxime, has exhibited nematostatic activity, but only at high concentrations (McGarvey et al., 1984). Our study was conducted to compare the decline of oxamyl residues in tomatoes stored in air and under two modified atmospheres.

\section{Materials and Methods}

The soil around the base of twenty $\approx 23$-week-old 'Caruso' tomato plants in a greenhouse was treated with $1.39 \mathrm{ml}$ Vydate L (24\% oxamyl liquid formulation; Du Pont Canada, Mississauga, Canada) in $200 \mathrm{ml}$ water. This is equivalent to the maximum recommended rate for soil application by drip irrigation for tomatoes (37.5 liters.ha' ${ }^{-1}$ ) (Du Pont, 1981). A preliminary experiment had shown that the oxamyl residue in tomato fruit on the vine increased during the first 3 days following soil treatment, and remained relatively constant for the following 12 days. Therefore,

\footnotetext{
Received for publication 14 June 1993. Accepted for publicationr 22 Oct. 1993, We thank Dianne M.L. Beaulieu-Aruvee for technical assistance and Mark Wolynetz, Perry Jui, and JoAnne Coutu-Sundy for help with statistical analysis. The cost of publishing this paper was defrayed in part by the payment of page charges. Under postal regulations, this paper therefore must be hereby marked advertisement solely to indicate this fact.
}

fruit were harvested for modified-atmosphere storage 3 days after treatment.

A total of 200 fruit were harvested on 28 May 1992 and divided into 40 samples of five fruit each (Expt. 1). Four replicate samples were immediately prepared for initial residue determination. The remaining 36 samples were placed, 3 per bag, in $91 \times 56$-cm low-density polyethylene bags (65 $\mu$ m thick) (Reyes, 1990) that were sealed with duct tape and flushed with $21.0 \% \mathrm{O}_{2}+79.0 \% \mathrm{~N}_{2}$ (air control), $1.5 \%$ $\mathrm{O}_{2}+98.5 \% \mathrm{~N}_{2}$, or $1.5 \% \mathrm{O}_{2}+4.0 \% \mathrm{CO}_{2}+$ 94.5\% $\mathrm{N}_{2}$ (Union Carbide Canada, Linde Division, Toronto). The bagged samples were newed with fresh gas mixture three times per week. One sample was removed from each bag at weekly intervals for 3 weeks (four replications per atmosphere), and the bags were immediately sealed and flushed with the appropriate gas mixture. In weeks 2 and 3, the fruit was rated for maturity based on a 6-point scale similar to the color classification standard used for U.S. no. 1 grade tomatoes (Table 1).

The fruit samples removed at weekly intervals were homogenized in a blender, and a 200 -g subsample was frozen in a 0.9-liter mason jar until extracted with $210 \mathrm{ml}$ methanol using a polytron homogenizer (Brinkman Instruments, Rexdale, Canada). Extracts were cleaned on solid-phase extraction cartridges containing $0.4 \mathrm{~g}$ Nuchar-Attaclay (McGarvey et al., 1986). Oxamyl was determined on a 1090 high-performance liquid chromatography (Hewlett-Packard, Mississauga, Canada) using a single-stage post-column derivatization reaction and fluorescence detection (McGarvey, 1989). An isocratic mobile phase, consisting of $15 \%$ or $20 \%$ acetonitrile in water, was used at a flow rate of $1 \mathrm{ml} \cdot \mathrm{min}^{-1}$ with a C-18 column. Four 200-g control samples of tomato spiked with $100 \mu \mathrm{g}$ oxamyl yielded a mean recovery of $83 \%(\mathrm{CV}=5.7 \%)$ using this method. Residue data were not corrected for incomplete recovery.

Using the same tomato plants, the experiment was repeated with seven replicate fruit stored at $15 \mathrm{C}$, and the atmosphere was re- samples per modified-atmosphere treatment per week (Expt. 2). Nine weeks after beginning Expt. 1, the soil around the base of each plant was treated with Vydate $\mathrm{L}$ at the same rate used previously. On the third day after treatment (21 July 1992), 350 fruit were harvested and divided into 70 samples of five fruit each. Seven samples were immediately prepared for initial residue determination. Three samples were placed in each of 21 storage bags, and seven bags each were filled with one of the three atmospheres. The same atmosphere maintenance and sampling methods were used as in Expt. 1.

Residue data were examined using repeated measures analysis (SAS Institute, 1990). Because the replicate-within-treatment term was not significant $(P>0.05)$ in both experiments, this error term was pooled with the residual error to give a more powerful test. Data were analyzed on both the original scale and after log transformation. Because the same patterns were observed in both cases, only the results based on the analysis of the original data are presented. In both experiments, repeated measures analysis indicated a significant time effect $(P<0.001)$ and a nonsignificant time $\mathrm{x}$ treatment interaction $(P>0.05)$. The latter indicated that the pattern of change was the same for all treatments. In Expt. 1, the overall treatment effect was borderline in significance $(P=0.052)$; whereas in Expt. 2, it was highly significant $(P<0.01)$. Because of the large time effect in both experiments, the data for each time were reanalyzed separately using a one-way analysis of variance (ANOVA) (Table 1). Maturity ratings of individual fruit were ranked within a given replication of all three treatments (a total of 15 fruit) at each time. One-way ANOVA of the ranked data and the raw maturity rating data provided the same result; therefore, only maturity rating data are presented (Table 1).

\section{Results and Discussion}

The mean oxamyl residue at week 0 was $0.32 \mu \mathrm{g} \cdot \mathrm{g}^{-1}$ in Expt. 1 and $0.16 \mu \mathrm{g} \cdot \mathrm{g}^{-1}$ in Expt. 2. The residue was lower in Expt. 2, probably because the older and taller vines had diluted the absorbed oxamyl to a greater extent.

In Expt. 1, the oxamyl residue in tomatoes stored for 3 weeks in $1.5 \% \mathrm{O}_{2}+4.0 \% \mathrm{CO}_{2}+$ $94.5 \% \mathrm{~N}_{2}$ was significantly lower than in those stored in air (Table 1). Experiment 2 confirmed this result with the difference being present after 2 weeks; after 3 weeks, tomatoes stored in either $1.5 \% \mathrm{O}_{2}+98.5 \% \mathrm{~N}_{2}$ or $1.5 \% \mathrm{O}_{2}$ $+4.0 \% \mathrm{CO}_{2}+94.5 \% \mathrm{~N}_{2}$ had significantly lower residues than those stored in air. Fruit ripening was significantly faster in air than in either $1.5 \% \mathrm{O}_{2}+98.5 \% \mathrm{~N}_{2}$ or $1.5 \% \mathrm{O}_{2}+4.0 \%$ $\mathrm{CO}_{2}+94.5 \% \mathrm{~N}_{2}$ (Table 1).

Interestingly, oxamyl residues declined most slowly in tomatoes that ripened at the fastest rate. Possibly, the nonripe tissue was better able to metabolize oxamyl than ripe, less physiologically competent fruit.

Oxamyl is stable under acidic conditions and hydrolyzes to oxamyl oxime slowly under neutral conditions, rapidly under alkaline con- 
Table 1. Weekly residues of oxamyl in and maturity ratings of tomatoes stored in three atmospheres.

\begin{tabular}{|c|c|c|c|c|c|}
\hline \multirow[b]{2}{*}{ Atmosphere } & \multicolumn{5}{|c|}{ Oxamyl residue ${ }^{z, y}\left(\mu \mathrm{g} \cdot \mathrm{g}^{-1}\right)$} \\
\hline & Wk 1 & \multicolumn{2}{|c|}{ Wk 2} & \multicolumn{2}{|c|}{ Wk 3} \\
\hline \multicolumn{6}{|c|}{ Expt. 1} \\
\hline $21.0 \% \mathrm{O}_{2}+79.0 \% \mathrm{~N}_{2}$ (air) & $0.35 \mathrm{a}^{\mathrm{x}}$ & $0.18 \mathrm{a}$ & $\left(3.1 \mathrm{a}^{\mathrm{x}}\right)$ & $0.24 \mathrm{a}$ & (4.2 a) \\
\hline $1.5 \% \mathrm{O}_{2}+98.5 \% \mathrm{~N}_{2}$ & $0.29 \mathrm{a}$ & $0.19 \mathrm{a}$ & $(1.5 \mathrm{~b})$ & $0.18 \mathrm{ab}$ & $(1.3 b)$ \\
\hline $\begin{array}{l}1.5 \% \mathrm{O}_{2}+4.0 \% \mathrm{CO}_{2}+ \\
94.5 \% \mathrm{~N}_{2}\end{array}$ & $0.29 \mathrm{a}$ & $0.15 \mathrm{a}$ & $(1.5 \mathrm{~b})$ & $0.09 \mathrm{~b}$ & $(1.2 \mathrm{~b})$ \\
\hline \multicolumn{6}{|c|}{ Expt. 2} \\
\hline $21.0 \% \mathrm{O}_{2}+79.0 \% \mathrm{~N}_{2}$ (air) & $0.12 \mathrm{a}$ & $0.07 \mathrm{a}$ & (4.1 a) & $0.04 \mathrm{a}$ & $(4.8 \mathrm{a})$ \\
\hline $1.5 \% \mathrm{O}_{2}+98.5 \% \mathrm{~N}_{2}$ & $0.10 \mathrm{a}$ & $0.06 \mathrm{ab}$ & $(2.2 \mathrm{~b})$ & $0.03 \mathrm{~b}$ & $(2.2 \mathrm{~b})$ \\
\hline $94.5 \% \mathrm{~N}_{2}$ & $0.08 \mathrm{a}$ & $0.04 \mathrm{~b}$ & $(2.2 \mathrm{~b})$ & $0.02 \mathrm{~b}$ & $(1.9 \mathrm{~b})$ \\
\hline
\end{tabular}

${ }^{2}$ Initial values were 0.32 and $0.16 \mu \mathrm{g}^{\mathrm{g}}{ }^{-1}$ for Expts. 1 and 2, respectively.

${ }^{y}$ Maturity rating is in parentheses. Rating scale was $1-6$, where $1=$ green, $2=$ breaker (tinge of pink), $3=$ turning, $4=$ pink, $5=$ light red, and $6=$ red.

${ }^{x}$ Mean separation in columns by LSD at $P<0.05$.

ditions (Du Pont, 1981). The pH of tomato fruit was not monitored during the residue study; however, the $\mathrm{pH}$ of 10 fruit after 1 week of storage was $3.97 \pm 0.13$ in air, $4.24 \pm 0.15$ in $1.5 \% \mathrm{O}_{2}+98.5 \% \mathrm{~N}_{2}$, and $4.25 \pm 0.21$ in $1.5 \%$ $\mathrm{O}_{2}+4.0 \% \mathrm{CO}_{2}+94.5 \% \mathrm{~N}_{2}$. The $\mathrm{pH}$ of fruit stored in air was significantly lower $(P \leq 0.05)$ than that of fruit stored in either of the modified atmospheres. The higher $\mathrm{pH}$ of fruit stored in modified atmospheres, therefore, may have contributed partly to the enhanced decline of oxamyl residues observed in fruit stored in those atmospheres.

This study showed that modified-atmosphere storage at a moderate temperature $(15 \mathrm{C})$ in $1.5 \% \mathrm{O}_{2}+98.5 \% \mathrm{~N}_{2}$ or $1.5 \% \mathrm{O}_{2}+4.0 \% \mathrm{CO}_{2}$ $+94.5 \% \mathrm{~N}_{2}$ enhanced the degradation rate of oxamyl and also delayed tomato ripening. To our knowledge, this is the first report of accelerated oxamyl degradation in modified-atmosphere storage.

\section{Literature Cited}

Du Pont. 1981, Vydate L insecticide/nematicide, technical bulletin. E.I. Du Pont de Nemours, Wilmington, Del.

Harvey, J., Jr. and J.C.-Y. Han. 1978. Metabolism of oxamyl and selected metabolizes in the rat. J. Agr. Food Chem. 26:902-910.

McGarvey, B.D. 1989, Liquid chromatographic determination of $N$ - methylcarbamate pesticides using a single-stage post-column derivatization reaction and fluorescence detection. J. Chromatography 481:445-451.

McGarvey, B.D., M. Chiba, and A.B. Broadbent. 1986. Simplified cleanup and capillary gas chromatographic analysis of residues of aldicarb and its oxidation products in chrysanthemum leaves. J. Assn. Offic. Anal. Chem. 69:852-855.

McGarvey, B.D., J.W. Potter, and M. Chiba. 1984 Nematostatic activity of oxamyl and N,Ndimethyl-1-cyanoformamide (DMCF) on Meloidogyne incognita juveniles. J. Nematol. 16:328-332.

Reyes, A.A. 1990. Pathogenicity, growth, and sporulation of Mucor mucedo and Botrytis cinerea in cold or CA storage. HortScience 25:549-552.

SAS Institute. 1990, SAS user's guide: Statistics. Version 6 ed. SAS Institute, Cary, N.C. 